\title{
Self Efficacy of Pre-Service English Teachers in Using English as a Language Instruction
}

\author{
Adria Rosy Starinne, \\ Universitas PGRI Ronggolawe,Tuban \\ adria_rosy@yahoo.com, \\ Dyah Kurniawati \\ Universitas PGRI Ronggolawe,Tuban \\ disakurnia@yahoo.com
}

Received: February 03, 2018 doi: $10.30587 /$ jetlal.v3i1.786
Accepted: Feruary 15, 2019

Url: http://dx.doi.org/10.30587/jetlal.v3i1.786
Published: February 27, 2019

\begin{abstract}
Field Experience Program or Praktek Pengalaman Lapangan (PPL) are carried out by students to fulfill the requirements for the formation of the education profession. But in the process of PPL, the pre-service English teachers of English Language Education Study Program at the University of PGRI Ronggolawe Tuban often experience problems related to their efficacy when teaching in English as language of instruction.

This study aims to determine the efficacy of English Language Education students who run the Field Experience Program (PPL) in using English as the language of instruction, as well as what factors influence their efficacy in using English as the language of instruction.

It is a phenomenological qualitative research which the choice of subject or data source was done by purposive sampling which focused on selected informants who were appropriate for in-depth studies (Nana Syaodih, 2007: 101). The subjects are pre-service English teachers who had finished undergoing PPL in the period between November 2017 to January 2018. Data collection techniques used are observation, interviews, and documentation, and using descriptive inductive analysis.

The results of this study reveal that self-efficacy of all pre-service English teachers (six students) as subjects in this study in terms of the use of English as the language of instruction during PPL has varied self-efficacy on dimensions of magnitude, strength and generality. Only 1 out of 6 students had negative self-efficacy in all dimensions, and 1 (one) person showed positive self-efficacy in all dimensions; magnitude, strength and generality. While the others vary for all three dimensions. Those six students used both English and Indonesian in teaching English. The reason was because they were not confident ( 2 people), and for the emphasis on certain material delivered so that it is more easily understood (4 people).

This study found that the factors of success experience and psychological factors were the strongest in forming self-efficacy of the 6 PPL pre-service teachers in using English as the language of instruction during field experience program. Furthermore, it is only slightly influenced by other people's success factors and social persuasion. The more experience and the better the psychological condition of students, the more positive their self-efficacy. Two students, namely $\mathrm{Mg}$ and $\mathrm{Su}$, have negative self-efficacy due to the lack of teaching experience and poor psychological conditions because they felt uncomfortable and underappreciated in the school where they carried out the field experience program.
\end{abstract}

Keywords: self-efficacy; pre-service English teachers; English

\section{Introduction}

The teacher is an educator who is very important in improving the quality of human resources. Chapter 1, Article 1 of the 2005 Teachers and Lecturers Act stated that teachers are professional educators with the task of educating, teaching, guiding, directing, training, and evaluating students in early childhood education in formal, elementary, and secondary education. As professional educators teachers need to have basic abilities or competencies. Based on Teacher and Lecturer Act, No 14 of 2005 and Government Regulation No. 19 of 2005 , teachers should have some competencies; personality (stable, mature, wise and prudent), pedagogic (understanding of students, designing and implementing learning, evaluating learning outcomes), professional 
(in-depth mastery of material), and social (good relations with the colleagues, students, parents / guardians , and education staff).

To reach these four competencies, a teacher must have confidence in self-ability to achieve learning goals. According to Ormrod (2008: 20) self-efficacy is a person's assessment of his own ability to carry out behavior or achieve certain goals. Self-efficacy is also interpreted related to a person's ability to regulate and decide en the actions needed to achieve the desired results. Moreover, Arifani \& Suryanti (2019) also assert that teaching style is another indicator of successful EFL teaching and learning. They further explain that the more creative teacher, the more successful classroom is.

It needs long process to build teacher efficacy which can be started since a prospective teacher has an education in college. Therefore as prospective educators, students are equipped with Micro Teaching skills to learn to teach with peers and then they have to take PPL (Praktek Pengalaman Lapangan) or teaching experience program to practice teaching in the real world of education.

Pre-service teachers often face many problem in conducting PPL program related with their self efficacy, in this case especially students who teach foreign languages such as English. They are not only faced with classroom management problems, adjusting the work environment and mastery of the material, but also linguistic problems as the language of instruction used during teaching process. In this case, the teacher should speak in English because the teacher is a model for students to imitate. In some cases, a prospective English teacher often uses Indonesian as the language of instruction, of course this is one of the obstacles in the process of transferring the knowledge of the language itself; teach English but still use Indonesian for communicating. They are not sure of their own abilities and feel that they cannot speak English well. It has been proved by by research of Puspita et all on Jember English literature faculty students. She revealed that efficacy to vocabulary and grammar had an effect on the formation of low self-efficacy. This is due to the lack of access and training undertaken by students considering they are learning English in an English language as a foreign language (Puspita et al, 2014: 52)

The same thing was also experienced by students of the English Language Education University of PGRI Ronggolawe Tuban who were undergoing the PPL period in some schools in Tuban Regency. These prospective English teachers often face the same problem related to their self-efficacy in using English as the language of instruction in the teaching process. Therefore, considering the importance of the efficacy of PPL students in using English as the language of instruction in teaching, this study aims to examine further the picture of self-efficacy of English Education Students at University of PGRI Ronggolawe Tuban and the factors that affect their self-efficacy when using English while implementing PPL or teaching experience program.

\section{Methods}

This research uses phenomenological qualitative research methods to develop understanding. The reason for choosing to use this method is because the qualitative approach interprete the basic interpretive and phenomenological views and this research is in accordance with the point of view in qualitative research. It considers that a social phenomenon is holistic (comprehensive, it cannot be separated), so in qualitative research it will not set its research based solely on research variables, but the overall social situation that is examined includes aspects of place, actor and activity that interact synergistically (Cokroaminoto: 2012).

This research was carried out in the scope of the University of PGRI Ronggolawe Tuban campus The subjects in this study were 6 English Language Education students who had finished undergoing PPL in the period of time between November 2017 and January 2018. Research was also conducted in several schools in Tuban district to get data from students who had been taught by the PPL students and some teacher mentors. In this study the subject as a source of data was done by purposive sampling which focused on selected informants who were rich in cases for in-depth studies (Nana Syaodih, 2007: 101), with different and various characters.

Data collection techniques used interviews, observation, and documentation. This study used nonparticipant observation, whereas the observer did not participate in the activities carried out by informants who were observed or only become observers. Observation used a behavior check list that focuses on the experience of the informant. Behavior check list was given to informants who know the behavior conditions of the main informants when they were teaching English (students and mentor-teacher). Documentation here is a technique of collecting data by recording events that occur in the field by utilizing existing secondary data. This study uses data obtained through interviews and observations so that it is analyzed by descriptive inductive analysis, which is to perform abstractions after recording specific phenomena grouped into one. Theories developed in this way 
emerge from below, which originate from a large amount of evidence collected that is interconnected with one another (Moleong, 2004: 5). To increase credibility in this study, researchers conducted triangulation. Triangulation is done by conducting interviews with some informants, they are people who are around the preservice teachers as the subject of the research.

\section{Results and Discussion}

Description of Self-Efficacy of Pre-Service Teachers of the English Language Education Study Program, the University of PGRI Ronggolawe Tuban in Using English as a Languange of Instruction

The researcher conducted qualitative in-depth interviewed with 6 (six) key informants who knows what is going on in the community, and they can provide insight of the nature of problems and represent the depth of data to be found. Determination of these informants varied representing informants who carried out teaching experience program (PPL) in some public schools that were considered reputable and key informants who completed PPL in either public or private schools with diverse reputations. The key informants in this study are $\mathbf{N u}, \mathbf{S y}, \mathbf{S u}, \mathbf{M g}$, Ti and No. The researcher also interviewed 11 supporting informants, they are 6 students (Lu, Sh, Ah, An, Ri, Ta) and 6 mentor teachers (Ru, Ag, En, Li, Tin and Wi). This study uses the basis of Bandura's self-efficacy theory which is then modified and adjusted. Bandura explains that self-efficacy consists of several aspects, namely magnitude, strength and generality. (Bandura, 1981; 1175-1184)

Table 1. Dimensions of Pre-service Teachers Self-Efficacy of English Language Education Study Program, University of PGRI Ronggolawe Tuban in Using English as the Language of Instruction

\begin{tabular}{lll}
\hline Dimensions & Positive self-efficacy & Negative self-efficacy \\
\hline Magnitude & $\mathrm{Mg}, \mathrm{Ti}, \mathrm{No}, \mathrm{Nu}$ & $\mathrm{Su}, \mathrm{Sy}$ \\
Strength & $\mathrm{Ti}, \mathrm{No}, \mathrm{Sy}, \mathrm{Nu}$ & $\mathrm{Mg}, \mathrm{Su}$ \\
Generality & $\mathrm{Ti}, \mathrm{No}, \mathrm{Sy}$ & $\mathrm{Mg}, \mathrm{Su}, \mathrm{Nu}$ \\
\hline
\end{tabular}

From the table above, it appears that 4 (four) out of 6 (six) students have positive self-efficacy on the dimensions of magnitude, namely $\mathbf{M g}$, Ti, No and Nu. The aspect of magitude or level refers to the level of difficulty that is believed by individuals to be resolved (Bandura in Rahmadini, 2011; 14). The four students were diligent in completing their assignments, they prepared the material well, had a high interest in something related to their duties, both in teaching and English.

According to Mrs $\mathbf{L i}$ as mentor teacher of $\mathbf{T i}$, $\mathbf{T i}$ is very smart, diligent and passionate. She always comes early for teaching, moreover she also completed her task very well. According to Mrs Li, Ti worked on the lesson plan well and right. She always submit her lesson plan she had made to Ms. Li before beginning her class, she also always uses interesting teaching media, for that reason the students love to join her classes. The following is an excerpt of an interview with Ms. Li:

"Wow, if there is such a pre-service teacher as Ti, I am happy, she is diligent, she eager to consult, make lesson plans, and she is always on time, that's what I like the most. She prepared everything, I saw her PPT slides yesterday, really good. And also she used posters and videos. '( $\mathbf{L i}$, personal communication, August 15, 2018)

Similar with Ti, No is also a student with an extroverted character. No seems as cheerful, loud talking, high self confidence and sociable person. According to Mrs. Wi (the mentor techer of No), No is a diligent student eventhough she is a relaxed person. She always comes on time, made lesson plans and tried to come to school before starting her teaching experience program to meet her mentor teacher and get personal approach to the students. Here is the statement of Mrs. Wi: 
"In my opinion, he is really fussy but she is good. She has a good intention for teaching. She never came late, befor wthe teaching program beginning she had come here first to meet me several times, and she also came in classes to see the students before teaching. Her lesson plan is good and it looks like she really prepares herself. '(Wi, personal communication, August 15, 2018)

The problem faced by No during her teaching practice is self-adjustment when starting teaching. He feels awkward, clumsy and nervous, but No can handle it by trying to cover up his anxiety by being relaxed and doing some jokes and small talks as she said below:

"It is difficult at the beginning..., when I came to the class at the first time, you know, I felt so awkward, nervous and confuse. How come? Feeling strange.... Yes, but I tried to stay relaxed by doing some joke and small talks to students in order to create more comfort and familiar situation" (No, personal communication, August 15, 2018)

No has a high interest in the tasks he is carrying out, she likes both teaching and English as subject matter, therefore she can finish her teaching experience program (PPL) happily. She believes that with his casual attitude and humor, she can overcome his anxiety. A sense of optimism in completing a task, a high interest of her responsibility and acting selectively in solving its problems are characteristics of people who have positive self-efficacy in the dimension of magnitude.

On the other hand, the pre service teacher, namely Su tends to have negative self-efficacy on the dimension of magnitude. Su tried to run away from her teaching experience program (PPL) at school X by trying to exchange places with her friend from another school, but her friend did not want to do so. Therefore Su compelled to conduct her teaching experience program at school $\mathrm{X}$. This is in line with the opinion of Zimmerman (2000, 82-91) that the nature of escaping from this difficulty is one of the characteristics of negative self-efficacy.

Sy also has negative self-efficacy on the magnitude dimension, because from the beginning of her teaching experience program she had the perception that she could not complete additional tasks to make modules and lesson plan for two semesters. The nature of the tasks assigned to her is not in accordance with the level of her capacity as a pre-service teacher. Sy must make a lesson plan for one year and student modules for two semesters. She considered that arranging lesson plans and modules for one school year is not in accordance with her capacity as pre service teacher who only did 4 times teaching experience program.

"It is hard to arrange lesson plans for 2 semesters, and more over she asked me to arrange English module ...." (Sy, personal communication, August 15 2018)

Sy made a lot of mistakes and needed time to exceed the limits in preparing lesson plan or modules. She always complains about her responsibility because he thinks it is not appropriate to her abilities. According to Bandura (2010), one indicator on the dimensions of magnitude or level is that someone is able to perform various tasks from easy to difficult (in Hadi, 2016; 14)

Ti, No and Sy have positive self-efficacy on the strength dimension. Individuals with self-efficacy on the positive strength dimension are individuals who have a strong belief that they will succeed even in difficult tasks. (Bandura in Sulistyawati, Nurtjahjanti, \& Prihatsanti, 2012; 145) They believe in their abilities, and they also try to improve their ability to speak English in various ways. Evenmore, No has over confidence related with her ability, so she always speaking English to everyone, even though that person doesn't know English at all.

"For the time being I often listen to western songs, imitate their songs, and try to talk with friends or other people always using English, even though the person is dumbfounded, but I try to translate. I also join English course in Pare "(No, personal communication, August 18, 2018)

Persistence is one of the personal characteristics with positive self-efficacy on the strength dimension. Other characters shown that No has positive self-efficacy on the strength dimension is she believes and know very well her abilities, as her statement below:

A: Do you feel your English is good and fluent?

B: Haaa ... absolutely, I'm sure, I'm always confident miss haaaa (No, personal communication, August 18 , 2018) 
No has over confidence, this can be seen from her daily attitude on campus and her statement that she always speaks in English with people who do not understand English, and he does not care about people's opinions about her. Here is the statement of An, one of her student ;

I like how the way she is teaching, but she always speaking English with everyone, even with teachers who are not English teachers, I sometimes get confused too, I didn't know what she was talking about (An, personal communication, August 18, 2018)

On the other hand, Mg has negative self-efficacy on the strength dimension, it can be indicated by her character which lack of persistent to communicate in English during teaching process. Mg has a very strong intention and desire to be able to speak English fluently, but he has not made any effort.

I don't have any chance to learn English, I don't get a partner to speak English. I onlu speak English in English class for presentation. I have never joint English course, maybe in the future (Mg, personal communication, July 17, 2018)

She felt embarrassed and discouraged because the students he taught mocked and ignored her when she asked them to speak in English. Since then he has switched to use Indonesian as the language of instruction. Here is her statement:

'Yeahh, what can be done. That what I have to do, I can't help it. But since they mock me I don't want to speak English anymore in that class. They don; t understand too. Finally I mox Indonesian and English, but much more in Indonesian." (Mg, personal communication, Juli 17, 2018)

Su has negative self-efficacy on the strength dimension, as she is not sure that she can speak English fluently. She is not too keen to improve her performance as an English teacher, as reviewed in the following interview:

“Who said I dont want to speak English fluently miss, but it is impossible, I'm shy and not pedantic." (Su, personal communication, July 17, 2018)

Su also did not make any effort to improve her English speaking skills even though she felt unsure of her own ability to speak in English

On the generality aspect, students who show positive self efficacy are Ti, No and Sy. The generality aspect shows whether individuals are able to have occupational self efficacy in many situations or in certain situations. Generality can be assessed from the same level of activity, ways of doing things where abilities can be expressed through cognitive, affective and conative processes, types of situations faced and individual characteristics in behaving according to purpose. (Bandura in Sulistyawati, Nurtjahjanti, \& Prihatsanti, 2012; 145). These students namely Ti, No, and Sy like challenges, and have broad expectations for their future. They do not rule out the possibility of wanting to work outside the academic field they are currently engaged in, not objecting to leaving their place of residence and family to achieve their dreams.

Ti is not only confident in her ability to teach English, but also she always seems optimistics, not fixated on bad experiences and thought that experiences was very important to improve her quality. Iit was stated in the following phrase:

"Mmmm ... I dont want to share my bad experiences, and it's not important to remember. What's important is in the future ... I have to be more careful in establishing relationships with other people. I don't want to tell you that. ... I want to teach at a good school, for example at International School, mom, kindergarten is ok, I will have great salary, and my English is definitely better as I meet many Caucasians over there "'(Ti, personal communication, July 21, 2018)

Positive self-efficacy on the generality dimension is also indicated by the nature of someone who likes new challenges and experiences. In this case Ti claimed that she like challenges and eager to get new experiences, she has broad expectations for her future:

"I want to be a guide too, it's fun, I can go anywhere... I want to go abroad, go around the world, have a lot of money and can make my parents happy"

(Ti, personal communication July 21, 2018) 
On the contrary, $\mathbf{M g}$ is not a person who likes challenges, she prefers to stay in her current zone, even though she realizes that the experience is important to her. She does not want to try new things nor going far from where she lives.

"I don't want to step outside of my comfort zone, I don't want to do diverse things. Just the way I am now, I'm afraid to go to Jakarta, just stay in Tuban” (Mg, personal communication, July 21, 2018)

Su even felt traumatized as a reaction to her bad experiences, she could not take lessons from what she experienced. The experience of teaching during field experience program made her traumatized and did not want to teach anymore, she felt the bad experience was not important and should not be repeated, but it was only good experience that she thought was important to experience. This implies that Su has negative self-efficacy on the generality dimension. Although she expressed pleasure in trying new things, but he did not want to teach anymore, she wanted to work in another field besides being a teacher.

Nu also has negative self efficacy in generality dimension. She felt that she was only able and wanted to work as an English teacher, she did not want to try another field because she was not sure that she could work in another field other than being an English teacher. In self-efficacy for the generality dimension, researchers found that she is actually an optimistic person, likes new things but is still within the field of interest (she calls it passion). She does want to work nor try different field. Her confidence is limited to the scope of her field, not in broader terms, as she revealed:

"A job which doesn't suit my passion is the worst experience .....I am happy with my new experience, but sometimes I need longterm adaptation.” (Nu, personal communication, August 15, 2018)

She was just fixated on the field she was in, and was reluctant to try other things outside of what she was currently engaged in. She thinks that she will be comfort if she keep staying in her current zone and do the same things as usual. She does not want work outside her subject (English), and she always avoid the different job or passion

"If I get new job and it is not appropriate with my subject, I will find another job, which is in accordance with my passion, because if we work according to our passion then we will love our work even though the rewards are not much." (Nu, personal communication, August 15, 2018)

Factors Affecting the Self-Efficacy of Pre-Service English Teachers of the English Language Education Study Program at the University of PGRI Ronggolawe Tuban in Using English as Language of Instruction

This research is analyzed based on the modified Bandura theory adapted to the conditions and findings. Bandura, 1997 (in Rustika, 2012; 19-22), self-efficacy is formed by several factors, namely (1) mastery experience. Humans go through experience of success and failure in their lives. Success will increase self-efficacy, otherwise failure will reduce one's self-efficacy. (2) Other people's experiences which fully internalized such as their own experiences (3) Verbal persuasion, is information that is intentionally given to people who want to change their efficacy, by providing encouragement that the problems they face can be solved (4) Physiological and mood conditions. In an activity that involves strength and stamina, people will interpret fatigue and pain as a guide to their efficacy. Likewise mood swings can affect one's beliefs about their efficacy. The 6 students' self-efficacy varies due to various factors.

Four (4) out of six (6) students had positive self-efficacy formed from the mastery of experience in using English as the language of instruction. Ti, No, Sy and Nu have had several years of teaching experience, both in formal and non-formal institutions. This proves the statement of Jess Feist and Gregory (2010: 212) which states that experience is the most influential source of self-efficacy, mainly the experience of mastering something in past performance. In general, successful performance will increase expectations regarding ability.

Sy used to use English as an language of intruction as she has been teaching both in elementary and secondary schools. Experiences made her efficacy self stronger, even though she actually had a shy and easily nervous nature. The following is one of interview script related to her teaching experience:

“... not bad, the students are very conducive, all this time. But I tried to prepare myself before teaching in order to master the material. Sometimes I practice for speaking English in front of the mirror. When teaching at the 
first time, I felt nervous and having a little bit fear, but day bay day I could manage it. It will be better if we have been familiar with the students." (Sy, personal communication, August 21, 2018)

It has been almost a year since $\mathbf{S y}$ taught at both institutions, and all this time he felt there were no significant obstacles when teaching using English as the language of instruction. According to her if she switched code from English to Indonesian, it was solely because she tried to make students understand better. Another experience is that when teaching colleagues in micro teaching. Sha said that teaching friends is much easier becauses he feels more relaxed and understandably.

One or the pre-service teacher, namely $\mathbf{N u}$ claimed that she is happy to be a teacher. She really enjoyed her teaching experience. She has been teaching in two junior high schools for two years as a contract temporary teacher. According to her, she did not have a bad experience when teaching, especially related to the use of English as the language of instruction. During this time she uses English combines with Indonesian because students often do not understand if she uses English as a whole.

"Nothing's wrong, everything is fine. Basically I like to teach, so I really enjoy it, I don't have any bad experiences in English teaching .... hmmm ... during speaking English I feel fine, students could understand. If they don't understand what I am talking about, I mix with Indonesian." (Sy, personal communication, August 21, 2018)

The experience of success in using English as language of instruction creates positive self-efficacy for $\mathrm{Nu}$. She admitted that she is very confident in speaking English with students, but not with foreigners who are native speakers of English, it can be because she is never keep in touch with English native speakers.

On the other hand, Su and Mg have negative self-efficacy as they do nont have prior teaching experience. Microteaching was their first teaching experience. They do not have teaching experience as private teacher nor teaching in institution. Moreover, Su often got bad experiences in the form of criticism or bad responses from her friends. Here is Su's expression:

"I know very well that I couldn't teach English, if I delivered presentations at college, lecturers often criticize my pronunciation. Moreover, I often repeat presentations. In a group work I alway feels guilty with my friends. I don't know what should I do in discussion or debate, it's very difficult for me to talk in English, even for memorizing." (Su, personal communication, August 21, 2018).

These unpleasant experiences related to her ability to use English at the time of presentation and micro teaching greatly influenced her confidence.

Su and Mg have negative sel efficacy from the modelling process as they often heard bad teaching experiences at school X from their seniors, so they felt anxious when they knew they are placed at that school. Actually, all key informants had heard about this bad news, but it did not affect them as they did not conduct their field teaching program at school $\mathrm{X}$.

"I often hear about this school, I tried to find out some informations about school X, one of the seniors actually scared me, he said wow, it will be good for mental training, he said so. Others said the students are all boys, stubborn and naughty. From the information I can conclude what school $X$ is like" (Su, personal communication, August 21, 2018)

Bandura, 1986 (in Ulfah, 2010; 10) proposes that the experience of success of others who have similarities with individuals in doing a task will usually improve one's self-efficacy in doing the same task. In this case the other 4 students namely $\mathbf{T i}$, No, Sy and Nu were not affected by the story of the bad experience of their senior at school $\mathrm{X}$ because they were not in the same location and situation, and they believed if they mastered the material, it was is not a problem as what No said.: 
"I heard the rumors about school X were terrible, but in the school where I conducted my PPL was not too stressful. But I think it is not important, I believe that wherever we teach if we master the material, we will not have problems." (No, personal communication, July 17, 2018)

Verbal persuasion is also a factor that influences one's self-efficacy. Information about one's abilities that are conveyed verbally by influental people is usually used to convince someone that she is capable enough to do a task. The 6 students had received praise or criticism from lecturers, mentor teachers and students they taught. According to Alwisol (2009: 289) verbal persuasion will strengthen and weaken one's self-efficacy, and the impact of this source is limited, but in the right conditions persuasion from other people can affect one's selfefficacy. This condition means trustworthiness to someone who assure her. In this case are the lecturers and the reality that occurs from what is persuaded. Su confessed that she often was criticized by lecturers or friends about her performance in English, both during presentation and the micro teaching process, as what she said:

"If the lecture is a kind-hearted person, she didn't tell anything, or just said "improve your English". But some other lectures complained me with their lemon faces, nobody praised me.” (Ti, personal communication, Sept 02, 2018)

Unlike Su, No and Nu often get praises or positive comments from their lecturers related to their ability to communicate in English. Whereas Ti, and Sy, although lecturers do not often praise them, but they often get admiration comments from students who they once taught. Here's her statement:

"There were no comments, the lecturer laughed and seemed happy, friends also responded me well, sometimes teasing funny, and all seemed to enjoy." (Ti, personal communication, Sept 02, 2018)

"He said I mastered of the material very well and the way how to convey material was interesting. Some lecturers and friends gave feedback. Sometimes I talk too fast, so it's hard to understand." (Nu, personal communication, August 2018)

$\mathrm{Mg}$ who are shy and quiet did not seem to get much positive or negative comments about their ability to communicate in English. It was because she had less experiences and moderate abilities, so it is not too prominent in the class.

Self-efficacy reflection that is grown due to psychological factors seems very influential on the 6 students in this study. According to Bandura (in Jess Feist and Feist; 2010, 213-215) self-efficacy can be learned and grown through several things, one of which is physical and emotional conditions. The anxiety theory speaking language by Horwitz (1986) was also developed to examine the more specific factors in this study, namely: 1) communication anxiety2) worries about the exam, 3) worries about negative evaluations made by the mentor teacher and students 4) feeling uncomfortable.

This study revealed that, in terms of the communication anxiety of the four informants, they did not feel worried about mispronunciation in speaking English, only $\mathrm{Su}$ and Sy were worried that they were often mistaken. Anxiety about not mastering the material only occurred in Su, while other informants did not worry about mastering the material, as expressed by Ms. En, the mentor teacher of $\mathbf{N u}$ :

"Her English is very fluent, how the way she conveyed the teaching material was very interesting, so the students felt happy What makes her confident is that ... this is my personal opinion, her English is good and she mastered the material”. (Mrs. En, personal communication, August 15, 2018)

The four students, Ti, No, Sy and Nu, did not seem to have too much trouble with their emotional condition during field experience program or PPL, they conducted their teaching practice in some schools where students were very conducive, active and very tolerant.

"Well, I am lucky, my students are well-behaved, they are obedient, silent and not noisy. We had fun, the class felt alive. I like doing PPL there, the students are polite and easily arranged, they are welcome." (Nu, personal communication, August 18, 2018)

On the other hand, $\mathrm{Mg}$ and $\mathrm{Su}$ who carried out teaching practices at school $\mathrm{X}$, received a poor response from the students they taught. Students who are unruly, noisy, busy doing other things in class and don't care about the lesson make $\mathrm{Mg}$ and Su frustrated. The two pre-service teachers were ridiculed about using English when teaching. 
"Hhhh ... I went mad, nervous, anxious, reluctant because they were ignored ... They talked and talked to their friends themselves. Throwing some papers to other students and not having seat quietly. I was ignored, I often felt annoyed because they imitated and tweaked my English with an annoying expression. If I talked in Indonesian they didn't reckon me, moreover if I speak in English, finally I teach using Indonesian”. (Su, personal communication, August 21, 2018)

This factor makes them reluctant to communicate in English with students at school X. This is in line with Krashen's hypothesis about affective filters (in Lightbow and Spada, 2006; 37), language learning in an inappropriate affective state will have a filter, or mental barrier, and this will prevent them from utilizing the full entry for further acquisition of linguistics. That is, anxiety causes an affective filter, which will prevent students from receiving input, and then their language acquisition will fail to make progress. Anxious, tense or boredom can cause a person's barrier to learning language. Woodrow (2006) further explained that foreign language anxiety is a problem in language learning and has a negative effect in speaking English for some students. This was experienced by Sy who admitted that indeed she did not use English fluently if she was in bad mood, but she could still overcome the situation, especially the orderly classroom situation and respectful students made her motivated.

"Sometimes I feel unconfident, when I am not in blue. I can teach properly and speaking English fluently when I am happy, if not I get nervous easily. I have been totally franic as I didn't master the material, but finally I can manage it and everything is ok. "(Sy, personal communication, August 15, 2018)

Both Su and Mg has negative self-efficacy due to more by psychological factors than other factors. They often feels nervous as they lack of mastery of material and lack of teaching experience. Mg, even though she felt mastered the material and there was no anxiety in pronouncing English words, but the negative response of students in the form of apathetic, unruly and do not respect the teacher makes her self-efficacy tend to be negative. Self-efficacy of Su tends to be negative not only because of lack of experience and lack of mastery of the material, but also mainly because her atmosphere at X school were stressful. The unruly and disobidient students makes her unhappy, so it created negative self-efficacy.

Su felt traumatized by the her bad experiences as she was ignored by her students. Completing her field experience program becomes a burden for her, more over she does not want to be teacher after all. Bandura (in Hadi 2016; 14) says that individuals with low occupational self efficacy will easily give up when experiencing unpleasant experiences, while individuals who have strong beliefs in their abilities will diligently try to face difficulties and obstacles.

\section{Conclusion and Suggestion}

\section{Conclusion}

From the description above, it can be concluded that the 6 (six) students as subjects in this study has varied self-efficacy on the dimensions of magnitude, strength and generality in using English as the language of instruction during their field experience program or PPL.

Su has negative self-efficacy on all dimensions, on the contrary Ti and No show positive self-efficacy in all dimensions; magnitude, strength and generality. Mg shows behavior that leads to an indication that she has positive self-efficacy on the magnitude dimension only, but her efficacy is negative for other dimensions. While

Nu has positive efficacy for the dimensions of magnitude and strength, but negative for the generality dimension. In general, it can be said that 2 (two) out of 6 students, namely Su and Mg were not too sure of their ability to use English as the language of instruction, so they almost used Indonesian while teaching. The 4 other students, namely $\mathbf{T i}, \mathbf{N o}, \mathbf{S y}$ and $\mathbf{N u}$, believed in their ability to use English as the language of instruction during their PPL practice, but they also tend to use Indonesian when teaching so that it is more easily understood by students in situations certain.

There are 4 (four) factors affecting self-efficacy of pre-service teachers in this study namely; experience of success (mastery experience), other experiences (modelling), verbal persuasion and psychological factors. Mastery experience and psychological factors are the strongest factors to form their self efficacy o in using English as the language of instruction. Only 2 (two) out of 6 (six) pre-service teachers had positive selfefficacy formed from the experience of success in using English as the language of instruction, namely Ti, No, Sy and Nu. Apart from their experience, they also conducted their field experience program at the "right" place 
where the school atmosphere is conducive, comfort and the students are easily regulated. With such an atmosphere the 4 students felt comfortable, as they were accepted and respected at that schools They also got the verbal persuasion factors from their prior experiences, the more they teach, the more their teaching skills and English improve, so they often hear and receive positive responses about their ability to use English, of course that increases their confidence.

Modelling factors or the influence of others do not influence the 4 students too much. Indeed, they often hear the experiences of others who are not good at implementing PPL at school X, but experiences makes them confident if they can handle it, moreover they conducted their PPL at different school.

While Mg and Su, have negative efficacy in using English as the language of instruction. This is due to some factors, mainly because of lack of experience in teaching, and psychological factors such as anxiety and discomfort because the students were unruled, troublesome and less respect to the pre-service teachers.

\section{SUGGESTIONS}

Based on the results of this study, the writer can provide some suggestion below;

a. The results of this study are expected to contribute to understanding the importance of self-efficacy of English or Foreign Language Education college students who implement field experience program or PPL. Furthermore, the decision makers of university can determine proper policies that can improve the self-efficacy of pre-service teachers, such as placing students in proper schools which is adapted to the character and abilities of pre-service teachers. For example students who lack experience should be placed in some schools whose students are easily managed, therefore preliminary study and investigation are significant to be done to know both the prior ability of the pre-service teachers and school inputs

b. For practitioners and scientists who are involved in the world of education are expected to be able to examine the results of this study, and make it as a discourse of thought in the development of science, especially in the science of educational psychology.

\section{References}

Alwisol. 2009. Psikologi Kepribadian. edisi revisi. Malang. UMM Press

Arifani, Y., \& Suryanti, S. (2019). The Influence of Male and Female ESP Teachers' Creativity toward Learners' Involvement. International Journal of Instruction, 12(1), 237-250. https://doi.org/10.29333/iji.2019.12116a

Arikunto, Suharsimi. 2006. Prosedur Penelitian suatu Pendekatan Praktik. Jakarta: Rineka Cipta

Andiny, L. 2008. Perbedaan Self-Efficacy Antara Guru SMA 'Plus' Dan Guru SMA Non 'Plus'. Skripsi. Depok: Fakultas Psikologi UniversitasIndones ia.

Bandura, A. 1997. Self-Efficacy The Exercise of Control. New York: W.H. Freeman and Company.

Bandura, 1981. Human agency in social cognitif theory American Psychologists. Journal of Personality and Social Psychology, (volume 44 no 9), hal 1175-1184

Cokroaminoto. 2014. Analisis Data Penelitian Kualitatif. http://www.menulisproposalpenelitian.com/2012/07/analisis-data-penelitian-kualitatif.html. Diaskses pada tanggal 28 Februari 2019, pukul 19.38.

Feist, Jess \& Feist, Gregory J.2010. Theories of Personality, 6th Edition, New York:McG Graw-Hills Companies.Inc

Hamalik, Oemar. 2008. Proses Belajar Mengajar. Jakarta:Bumi Aksara 
Henson, R.K.2001. Teacher Self-Efficacy:Substantive Implication and Measurement Dilemmas. Paper Presented by Annual Meeting of the Educational Reseach Exchange, January 26, 2001,Texas A\&M Universty, College Station,Texas.

Lightbown, P. M. \& Spada, N. 2006. How languages are learned (3rd ed.). Oxford: Oxford University Press.

Moleong, Lexi.J, 2004. Metode Penelitian Kualitatif. Bandung: Remaja Rosdakarya

Mawanti, Dwi.2011. Studi Efikasi Diri Mahasiswa yang Bekerja Saat Penyusunan Skripsi. Skripsi.Semarang. Fakultas Tarbiyah

Myers, D.G. (2012). Psikologi Sosial (Aliya Tusyani, Lala Septiani Sembiring, Petty Gina Gayatri, dan Putri Nurdina Sofyan, Penerjemah). Jakarta: Penerbit Salemba Humanika.

Ormrod, J.E. 2003. Educational psychologydeveloping learners. Fourth Edition. Ohio: Person Education.

Peraturan Menteri Pendidikan Nasional Republik Indonesia No. 19 Tahun 2005.Tentang Standar Nasional Pendidikan. (Online).

(http://www.fti.itb.ac.id/wp-content/uploads/2015/06/pp-19-tahun-2005-tentang-Standar-PendidikanNasional. html, dikunjungi 5 Febuari 2015).

Puspita dkk .November 2014. Level and Sources of Self Efficacy in Speaking Skills of Academic Year 2012/2013 English Department Students Faculty of Letters, Jember University. Publika Budaya, Volume. 3 (2): hal 50-59

Rahmadini, A.P. 2011. Studi Deskriptif mengenai Self Efficacy terhadap Pekerjaan pada Pegawai Staf Bidang Statistik Sosial di Badan Pusat Statistik Provinsi Jawa Barat, Skripsi, Bandung; Fakultas Psikologi Universitas Islam Bandung

Rustika, I Made. 2012. Efikasi Diri: Tinjauan Teori Albert Bandura, Fakultas Psikologi, Universitas Gajahmada. Buletin Psikologi, VOLUME 20, NO. 1-2, 2012: 18 - 25

Santrock, John W. 2007. Perkembangan Anak, Edisi ke-11 Jilid 1.(Penerjemah: M. Rahmawati dan A. Kuswanti). Jakarta: Erlangga.

Syaodih, Nana Sukmadinata. 2007. Landasan Psikologi Proses Pendidikan. Bandung: PT Remaja Rosdakarya.

Sugiyono. 2014. Metode Penelitian Kuantitatif, Kualitatif, dan R\&D. Bandung: Penerbit Alfabeta.

Sulistyawati, R., Nurtjahjanti, H., \& Prihatsanti. U. 2012. The Relationship Between Work Efficacy With Job Insecurity On Production Employees PT “X” Semarang. Jurnal Psikologi, Vol: 1, No: 1, Tahun 2012, Hal. 139-153.

Ulfah, Siti Hadijah. 2010. Efikasi Diri Mahasiswa Yang Bekerja Pada Saat Penyusunan Skripsi. Malang.

Fakultas Psikologi Universitas Muhammadiyah Surakarta

Woodrow, L. 2006. Anxiety and speaking English as a second language. In: RELC Journal, vol. 37, n. 3, pp. 308-328. ISSN 0033-6882.

Yuliani, A. E. 2013. Kontribusi Efikasi Guru Terhadap Minat dan Sikap Siswa di SMA Negeri Kabupaten Pandeglang. Skripsi. Bandung: Universitas Pendidikan Indonesia.

Zimmerman, B. J. (2000). Self efficacy: An Essential Motive to Learn. Contemporary Educational Psychology 25, 82-91. Graduate School and University Center of City University of New York.

Zuldafrial \&Lahir.2012. Penelitian Kualitatif. Surakarta: Yuma Pustaka 